IRA-International Journal of Management \& Social Sciences

ISSN 2455-2267; Vol.06, Issue 03 (2017)

Pg. no. 495-499

Institute of Research Advances

https://research-advances.org/index.php/RAJMSS

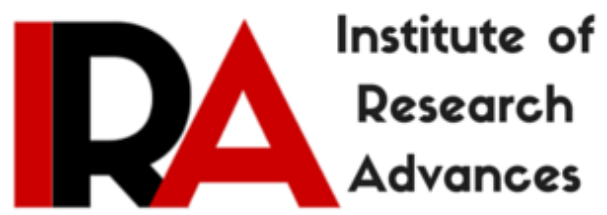

\title{
Paradigm Shift from Market Driven to Market Driving Strategy in Smartphone Handset Industry: A Comparison
}

\section{Prof. Satish Agarwal}

Professor, Maharishi Dayanand Saraswati University, Ajmer, India.

Priyanka Bhagoliwal

Research Scholar, Maharishi Dayanand Saraswati University, Ajmer, India.

Type of Review: Peer Reviewed.

DOI: http://dx.doi.org/10.21013/jmss.v6.n3.p14

\section{How to cite this paper:}

Agarwal, S., \& Bhagoliwal, P. (2017). Paradigm Shift from Market Driven to Market Driving Strategy in Smartphone Handset Industry: A Comparison. IRA-International Journal of Management \& Social Sciences (ISSN 2455-2267), 6(3), 495-499. doi:http://dx.doi.org/10.21013/jmss.v6.n3.p14

(C) Institute of Research Advances

(cc) EY-NC

This work is licensed under a Creative Commons Attribution-Non Commercial 4.0 International License subject to proper citation to the publication source of the work.

Disclaimer: The scholarly papers as reviewed and published by the Institute of Research Advances (IRA) are the views and opinions of their respective authors and are not the views or opinions of the IRA. The IRA disclaims of any harm or loss caused due to the published content to any party. 


\begin{abstract}
Marketing has changed rapidly over time. Especially the Hi-Tech Industry has shifted its marketing strategies from traditional customer driven strategies to modern customer driving strategies. Customer driven market strategies focused on understanding the needs of the customers and satisfying those needs whereas customer driving strategies deals with generating needs, creating value proposition and delighting the customers by providing new-to-the-world products. The paper focused on the fundamentals of both the market driven and market driving strategies. It provides a comparison between both the strategies and concludes that hi-tech industry has successfully adopted the market driving strategies.
\end{abstract}

Keywords: Smartphones, Market driven strategies, Market driving strategies, crowd sourcing, value proposition

\title{
1. Market driven strategies
}

Market driven is a customer-oriented strategy. Day (1999a) stated that market-driven denotes a "superior ability to understand, attract, and keep valuable customers". Market driven strategy focus on understanding the needs of the customers and delivering a product to satisfy those needs. It forecast the demand of the market and then supplies the products and services to fulfill the demand. Market driven strategic practice includes careful market research, investigating the customers' needs, and developing differentiated products or services for a well-defined segment. Various companies such as Nestle, Procter \& Gamble, and Unilever have effectively employed this market driven approach and succeed. A firm that is market driven is both customer oriented and market oriented. A supply chain was introduced which caters and respond to the consumer desires. This chain, which serves the ultimate master, that is, consumer, is the demand chain. Demand chain is consumer driven as it uses consumer knowledge to develop products (Roger.D.Blackwell, 1997). This demand chain is the market driven strategy which relates to a company's ability to learn and understand the customers' needs and demands and respond to the market.

\subsection{Customer orientation}

A market driven organization have superior market sensing, customer linking and channel bonding capabilities (George S Day, 1999). The process of market sensing follows market information acquisition, information distribution, interpretation, information utilization, evaluation of outcomes (Day, 1999). Customer linking involves creating and managing close customer relationship and channel bonding comprises activities such as order planning, order generation, prioritization, scheduling, order fulfillment, billing and payment (Day).

\subsection{Market orientation}

Market oriented companies determine its distinctive capabilities to create superior customer value so as to retain potential customers and to add more customers (Freddy Rangkuti, 2007). It deals with analyzing and learning the market conditions, acquiring information related to the ongoing market demand and having a strong internal communication within the firm. (Dr. Dan 2011) 


\subsection{Crowd sourcing}

A new concept of crowd sourcing was introduced by Jeff Howe. Howe says "crowd sourcing is a process in marketing where customers are asked suggestions on aspects with references to the products, advertisements etc. in return of prizes. It can occur online or offline and is often restricted to the employees and their family. (Jeff Howe, 2006). Today sales person has to sell product the way customer want to buy since every individual has different motives and their motives will only be understood if the role is changed from a sales person to a sales advisor. An engaged customer is very different from a merely satisfied one.

\section{Market driving strategies}

In this hypercompetitive climate where there are new products regularly entering the market, firms need to come out of their comfort zones and manufacture products which gives an entirely new experience to the customers and ultimately delight them. One thing that makes business difficult is the uncertainty and complexity of competition and change; particularly in fast moving markets. Business is an interconnected race between companies to secure additional business. What one supplier loses another secures. It is a zero sum game. Therefore an individual firm must move rapidly to arrive at the opportunity before their peer businesses. If there is currently no competition in an area, there soon will be. (Marc A Annacchino, 2003). To compete successfully, managers need to be able to scan their environment, identify relevant opportunities and threats, to design responses that will satisfy customers in ways that competitors can't easily imitate, and finally, to ensure that these plans are implemented, even as the firm competes across a variety of geographies and markets and in mature business as well as emerging. ( $\mathrm{J}$ Bruce. Harreled, Charles A O'Reilly II, Michael L Tushman, 2007). Market driving is a forward looking approach which focuses on a vision for the future and does not use the traditional methods and norms of new product development (Andrew Stein, 2012). Market driving relates to the company's ability to change the market (Kumar, Scheer and Kotler 2000). Firms do not need to strictly follow their customers' voice; they can drive the market and lead their needs in new directions by dramatically increasing the customer value proposition, a strategy best described as marketdriving (Harris and Cai 2002; Jaworski, Kohli, and Sahay 2000; Kumar, Scheer, and Kotler 2000). Market-driving organizations are better able to gain a sustainable competitive advantage by changing the structure or composition of a market and/or behaviors of its players (Jaworski, Kohli, and Sahay 2000).

\subsection{Need generation}

Market driving companies earn competitive advantage in an entierly different way. In market driving strategy, the companies make the buyer to unlearn and then learn. It makes the buyer learn why they need the product and hence creates a demand. Hence now a day, Market places are focused on creating customer needs and wants. The companies offer new-to-theworld products and teach the buyers about the importance and usability of the product create value and logic for choosing the product. It changes the fundamentals of business through innovation and teaches the potential customers adopt their value proposition. (Kumar, Scheer and Kotler). 


\subsection{Value addition}

A value based pitch can woo customers who did not realize they needed your product. Value proposition refers to the combination of benefits, acquisition efforts/costs, and price offered to customers. The market-driving organization is likely to propose offerings more valued by consumers than competitors (Carrillat, Jarmillo and Locander, 2004). Such organizations shape the market and delight the customers with product innovation according to their own competencies and hence gain competitive edge over other market driven companies. It is a more strategic and proactive approach through which a firm creates value by performing innovative activities both within an organization and outside it (Deshpande, Rohit, 2000). It acts as a catalyst or a change agent; it compels other industries to follow them in new direction. Hence the three dimensions of market driving firms are Value creation, Change and leadership (Stacey Barlow hills-and Shikhar Sarin, 2003).

\section{Conclusion}

As we see that the hi-tech industry is moving at a fast pace. There is hyper competition in the hi technology industry as new products and services are continuously introduced. To gain competitive advantage in such a scenario, it is important for the competitors to make a shift in their marketing strategies. Market driving strategies have proved beneficial for the companies as compared with the market driven strategies. The market driving strategies not only satisfies the customers but also delight them by overwhelming their expectations and providing product which they have not thought of. The companies then make the buyers learn about the need of the product and teach them the value proposition. This buyer learning makes a different set of competition. These strategies reshape the market and define the concept of value. Hence the market driving strategies are superior then the market driven strategies. Companies adopting market driving strategies create markets, which are beyond customer's imagination and attain competitive advantage.

\section{References}

1. Andrew stein, 9 Differences Between Market Driven and Market Driving Companies, blog, steinvox.com, October 31, 2012.

2. Deshpande, Rohit 2000, Creating Value, Harvard Business School, Teaching note, $3^{\text {rd }}$ October.

3. Dr. Dan, Market Orientation, blog, November 7, 2011.

4. Francois A Carillat, Fernando Jaramillo, William B Locander. Market Driving OrganizationA Framework, Academy of Marketing Science Review, Vol 2004 no.5. Available: http://www.amsreview.org/articles/carrillat05-2004.pdf

5. Freddy Rangkuti, Understanding Market Driven Strategy, Article, Published date September 23,2007. www.insidebusiness360.com

6. George S Day 1999, The Capabilities of Market Driven Organization, Journal of Marketing, Vol 58 (October 1994), 37-52.

7. Harris, Lloyd C. and Kai Y. Cai (2002), Exploring market driving: A case study of De Beers in China, Journal of Market-Focused Management 5(3), 171-196.

8. J Bruce Harreld, Charles AO'ReillyII and Michael L Tushman, "Dynamic Capabilities at IBM-Driving Strategy in Action", California management 2007, Vol49, No:4, Summer 2007, University of California, Berkeley. 
9. Jaworski Bernard, Ajay Kohli, Arvind Sahay 2000, "Market driven versus Driving Markets", Journal of Academy of Marketing science, Vol 28, No.1, Pages 45-54. Available online: http://link.springer.com/article/10.1177\%2F0092070300281005\#page-2

10. Jeff Howe, The Rise of Crowd Sourcing, 2006, Online article, Published in online magazine 'Wired'.

11. Marc A. Annacchino, 2003 "New Product Development; From Initial Idea to Product Management", published by Elsevier Butterworth-Heinemann.

12. Nirmalya Kumar, Leesa Scheer and Philip Kotler (April 2000), "From Market Driven to Market Driving", European Management Journal, Vol 18, No 2, pp 129-142. http://218.248.31.202/librarymain/files/casestudies/FromMarketDriventoMarketDriving.pdf

13. Roger.D.Blackwell , 1997 "From Mind to Market", $1^{\text {st }}$ edition, published by Harper Business.

14. Stacey Barlow Hills and Shikhar Sarin, "From Market Driven to Market Driving, An Alternate Paradigm for High Technology Industries", Journal of Marketing Theory and practice, 11(3), 13-24, summer 2003. Available online: http://works.bepress.com/cgi/viewcontent.cgi?article=1007\&context=shikhar_sarin 